\title{
Glucose-6-phosphate Dehydrogenase (G6PD) Deficiency, Abnormal Haemoglobins, and Thalassaemia in Yugoslavia*
}

\author{
G. R. FRASER, $†$ P. GRUNWALD, and G. STAMATOYANNOPOULOS +
}

From the Division of Medical Genetics, Dept. of Medicine, School of Medicine, University of Washington, Seattle, U.S.A.; Institute of Biology, Faculty of Medicine, Zagreb, Yugoslavia; and Department of Clinical Therapeutics Faculty of Medicine, Alexandra Hospital, Athens, Greece

Yugoslavia is a country where, until recently, endemic malaria was widely prevalent (Fig. I modified from Simić (1956)). In these malarious regions infestation with Plasmodium vivax, $P$. malariae, and $P$. falciparum occurred. In view of the repeatedly reported presence of G6PD deficiency, thalassaemia, and abnormal haemoglobins in neighbouring Greek and Italian populations, and in view of suggestions that selective advantage of heterozygotes in regard to malaria plays a role in the maintenance of polymorphisms involving these genes (Motulsky, r964), a screening survey was performed in the summer of 1962 to obtain some idea of the frequency of these conditions in Yugoslavia. Areas for the collection of blood samples were all selected on the basis of particularly heavy past malarial infestation (Fig.).

\section{Material and Methods}

Blood was taken by venepuncture into acid citrate dextrose (sometimes with added inosine), preferentially from males (493 males, I63 females), and sent to Seattle by air in ice-cooled vacuum flasks. The samples arrived usually within seven days of collection in good condition for the determination of G6PD activity. Subsequently 560 samples were haemolysed and sent to the Laboratory of Haematology of the Department of Clinical Therapeutics in the University of Athens for examination of abnormal and normal haemoglobin fractions by starch gel electrophoresis. This was supplemented in

Received March 1, 1965.

* This study was supported by U.S Public Health Service Grant H 309r.

† Present address: Department of Genetics, University of Adelaide, Australia.

¥ Present address: Division of Medical Genetics, School of Medicine, University of Washington, Seattle, U.S.A. most cases (470) by study of a blood film, made at the time of the original venepuncture.

Table I indicates the number of specimens and the sex of the persons sampled in each of the I collecting areas. Series B, D, E, H, I, K, and L consisted of patients in hospital. As in each case the hospitals concerned served a large area, the origin of the patients was not as circumscribed as the Figure would indicate. The persons sampled were of all age-groups, though few children were included. Related persons were excluded. For every individual the age and place of birth was obtained. The gypsies of Skopje (represented by Series C) are a most unusual isolate of several thousand persons who occupy their own quarter in the town. It seems that the gypsies of the Balkans and of Europe in general came from India and certainly the physical appearance of many of the gypsies of Skopje is akin to that of presentday Indians (Schade and Pilarić, 196I).

TABLE I

ORIGIN, NUMBER, AND SEX OF INDIVIDUALS SAMPLED IN SURVEY

\begin{tabular}{|c|c|c|c|c|}
\hline Series & Place of Origin & Males & Females & Total \\
\hline \multirow[t]{2}{*}{$\begin{array}{l}\mathbf{A} \\
\mathbf{B} \\
\mathbf{C} \\
\mathbf{D}\end{array}$} & $\begin{array}{l}\text { Gevgelija } \\
\text { Stip } \\
\text { Gypsies of Skopje } \\
\text { Skopje }\end{array}$ & $\begin{array}{l}24(0) \\
26(14) \\
34(17) \\
22(7)\end{array}$ & $\begin{array}{l}\text { Is (0) } \\
\text { I5 (2) } \\
8(8) \\
0(0)\end{array}$ & $\begin{array}{l}39(0) \\
41(16) \\
42(25) \\
22(7)\end{array}$ \\
\hline & $\begin{array}{l}\text { Macedonia- } \\
\text { Total (A-D) }\end{array}$ & $106(38)$ & $38(10)$ & $144(48)$ \\
\hline \multirow[t]{2}{*}{$\begin{array}{l}\mathbf{E} \\
\mathbf{F} \\
\mathbf{G} \\
\mathbf{H} \\
\mathbf{I} \\
\mathbf{K} \\
\mathbf{L} \\
\mathbf{M}\end{array}$} & $\begin{array}{l}\text { Dubrovnik } \\
\text { Ston } \\
\text { Metkovic } \\
\text { Split } \\
\text { Zadar } \\
\text { Biograd } \\
\text { Rijeka } \\
\text { Mavrovo (Nr. Rijeka) }\end{array}$ & $\begin{array}{l}34(14) \\
55(50) \\
19(16) \\
62(53) \\
27(19) \\
61(60) \\
126(119) \\
3(3)\end{array}$ & $\begin{array}{l}27(9) \\
11(10) \\
19(13) \\
19(14) \\
1(0) \\
37(33) \\
0(0) \\
11(9)\end{array}$ & $\begin{array}{l}61(23) \\
66(60) \\
38(29) \\
81(67) \\
28(19) \\
98(93) \\
126(119) \\
14(12)\end{array}$ \\
\hline & $\begin{array}{l}\text { Dalmatian coast- } \\
\text { Total (E-M) }\end{array}$ & $387(334)$ & $125(88)$ & $512(422)$ \\
\hline
\end{tabular}

Note: Numbers in brackets indicate numbers from whom blood films as well as blood was available. 


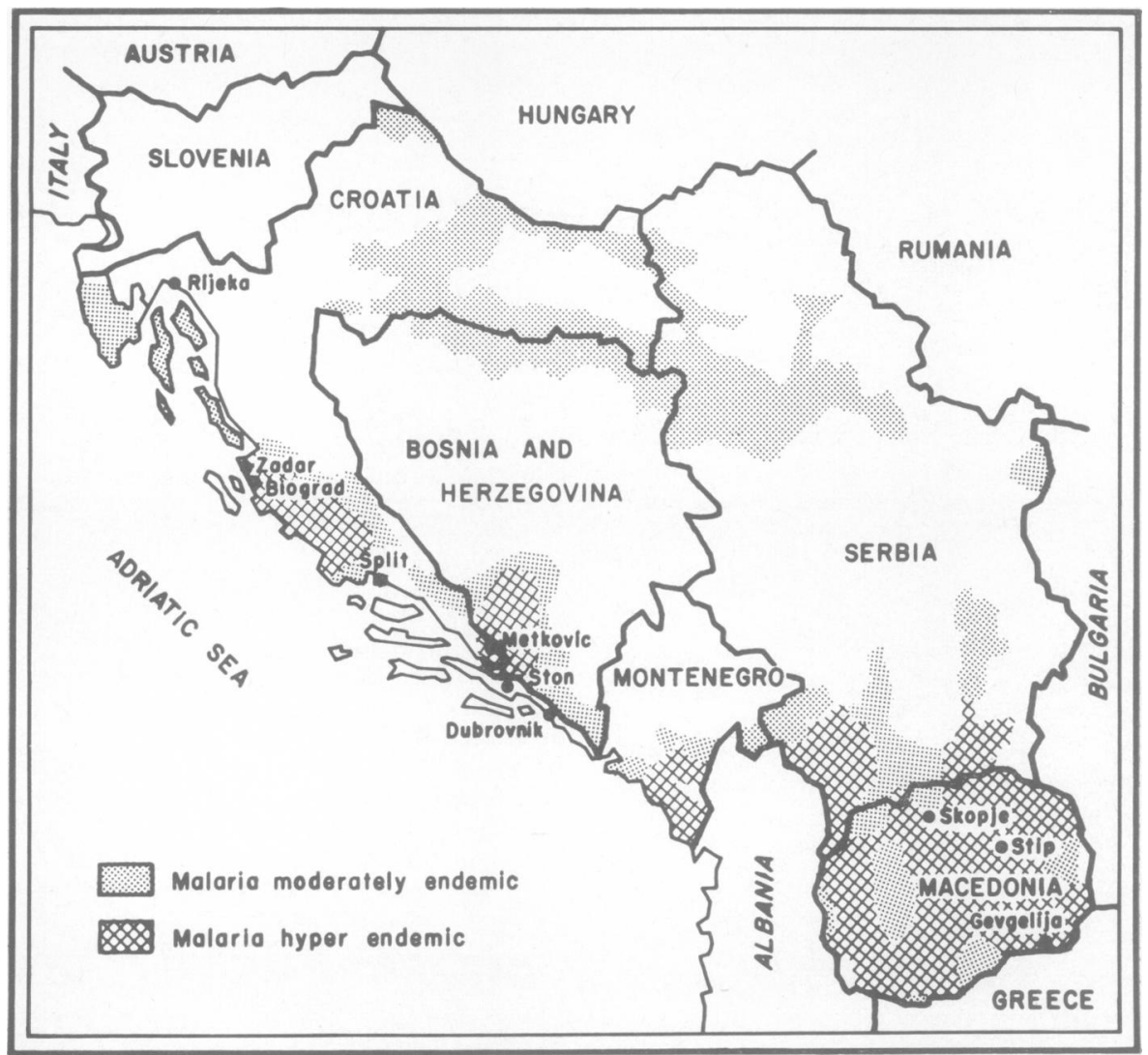

FIG. Map of Yugoslavia showing towns where blood samples were obtained.

In the detection of G6PD deficiency the brilliant cresyl blue (BCB) decolorization test (Motulsky and Campbell-Kraut, I96r) was employed. In 28 females ( 5 belonging to series $A, 15$ to series $B$, and 8 to series $C$ ), the methaemoglobin reduction test (Brewer, Tarlov, and Alving, I960) was used in addition. These were specimens in which inosine $(2.4 \mathrm{~g} . / 100 \mathrm{ml}$.) had been added to the acid citrate dextrose anticoagulant. This additive ensures that the results of the test remain reliable for 7-I4 days from collection of the sample. No inosine was added to the blood samples from males or from the remaining females and the methaemoglobin reduction test was not possible in these cases.

Details of methods for the detection of thalassaemia have previously been described (Malamos, Fessas, and Stamatoyannopoulos, 1962). ACD was selected as the anticoagulant in this study because of its suitability for the determination of G6PD deficiency. It is not appropriate, however, especially after a delay of several days, for the study of the haematological criteria of thalassaemia, such as changes in osmotic fragility, red cell counts, and haemoglobin levels. Since the presence of a raised proportion of haemoglobin $\mathrm{A}_{2}$ could also now be studied, the samples not being in sufficiently good? condition, only the morphological characteristics of the erythrocytes remained as a possible indicator of the diagnosis of thalassaemia.

Finally in the males of series $A, B, C, D, F$, and $G_{D}$ screening tests for red-green colour blindness using Ishihara plates were performed.

\section{Results}

G6PD Deficiency. With the exception of 5 , alf samples from males decolorized the BCB in les\$ than 65 minutes, indicating normal enzyme activity. In the case of two samples from series the times were 130 and 160 minutes and 1935 minutes in one sample from series $L$. In series $C^{\prime}$ one time of 105 minutes and one of more than 240 hours were recorded.

Of the 28 females tested no less than 4 showed abnormalities with the methaemoglobin reduction 
test ( 2 from series $B$ and 2 from series C). Of these 4,3 also showed abnormal results with the BCB decolorization test (I44 minutes, I03 minutes, more than 24 hours). While in the fourth the BCB decolorization time was normal, it is known that this test is less reliable than the methaemoglobin reduction test in the detection of females heterozygous for the gene determining G6PD deficiency. Abnormal BCB decolorization times were not recorded in the remaining 135 samples from females in whom the methaemoglobin reduction test was not performed. It is worthy of note that of the 9 persons who gave results indicative of reduced G6PD activity, only one (a male of series L) was a hospital patient. It does not seem likely, therefore, that the enzyme deficiency in these individuals is related in any way to illness.

Abnormal Haemoglobins. A high level of foetal haemoglobin (10\%) was found in a male of series L. His blood film showed no morphological abnormalities of the erythrocytes. In another male of the same series an abnormal haemoglobin with the characteristics of haemoglobin Pylos (Fessas, Stamatoyannopoulos, and Karaklis, 1962) was found. Unfortunately no blood film was available from this individual.

Thalassaemia. Morphological erythrocyte abnormalities highly suggestive of $\beta$-thalassaemia trait were found in a large number of cases (Table II). The total of probable and possible cases represents $7.5 \%$ of the persons sampled, which corresponds to a prevalence almost exactly similar to that found in a much larger sample of military recruits in
Greece (Malamos et al., 1962), though the findings presented here cannot be regarded to be as reliable as those of the Greek survey for the reasons already mentioned. Furthermore, in the Greek series no selection was made, as in the present one, to include preferentially persons originating from past foci of hyperendemic malaria, and it is known that in some areas of Greece considerably greater prevalences of $\beta$-thalassaemia than the average prevail (Stamatoyannopoulos and Fessas, 1964).

The slightly higher prevalence in the women sampled (10.2\% as opposed to $6.7 \%$ in males), while not statistically significant $\left(\chi_{1}^{2}=0.91\right)$, suggests that a few of the 35 cases, especially in the possible group, represent iron-deficiency anaemia which is expected to be more common in females and which leads to somewhat similar morphological abnormalities of the erythrocytes to those seen in $\beta$-thalassaemia. There is no suggestion, however, that hospital patients are over-represented among the cases of suspected $\beta$-thalassaemia. In fact the incidence of abnormal blood films is lower among hospital patients $(6.7 \%$ as opposed to $9.2 \%$ in non-hospitalized persons). It is unlikely, therefore, that the morphological abnormalities detected in this survey are associated with diseases requiring hospital treatment rather than with $\beta$-thalassaemia trait.

Red-green Colour Blindness. Of 72 Macedonians tested (series A, B, D), 4 (5.6\%) were colour blind. Of 34 gypsies (series C), $2(5.9 \%)$ were colour blind, and of 75 Dalmatians of series F and G, 3 $(4.0 \%)$ were colour blind. The defect was of the deutan type in 7 cases and protan in 2 (one Macedonian and one gypsy).

TABLE II

PROBABLE AND POSSIBLE CASES OF $\beta$-THALASSAEMIA IN PERSONS SURVEYED

\begin{tabular}{|c|c|c|c|c|c|c|c|c|c|c|}
\hline \multirow{2}{*}{ Series } & \multicolumn{3}{|c|}{ No. of Slides Taken } & \multicolumn{3}{|c|}{ No. of Probable Cases } & \multicolumn{3}{|c|}{ No. of Possible Cases } & \multirow[t]{2}{*}{ Percentage } \\
\hline & Male & Female & Total & Male & Female & Total & Male & Female & Total & \\
\hline $\begin{array}{l}\mathbf{A} \\
\mathbf{B} \\
\mathbf{C} \\
\mathbf{D} \\
\mathbf{E} \\
\mathbf{F} \\
\mathbf{G} \\
\mathbf{H} \\
\mathbf{I} \\
\mathbf{K} \\
\mathbf{L} \\
\mathbf{M}\end{array}$ & $\begin{array}{r}0 \\
14 \\
17 \\
7 \\
14 \\
50 \\
16 \\
53 \\
19 \\
60 \\
119 \\
3\end{array}$ & $\begin{array}{r}0 \\
2 \\
8 \\
0 \\
9 \\
10 \\
13 \\
14 \\
0 \\
33 \\
0 \\
9 \\
\end{array}$ & $\begin{array}{r}0 \\
16 \\
25 \\
7 \\
23 \\
60 \\
29 \\
67 \\
19 \\
93 \\
119 \\
12\end{array}$ & $\begin{array}{l}0 \\
2 \\
2 \\
0 \\
1 \\
0 \\
0 \\
3 \\
3 \\
2 \\
5 \\
0\end{array}$ & $\begin{array}{l}0 \\
0 \\
0 \\
0 \\
1 \\
1 \\
2 \\
1 \\
0 \\
0 \\
0 \\
1\end{array}$ & $\begin{array}{l}0 \\
2 \\
2 \\
0 \\
2 \\
1 \\
2 \\
4 \\
3 \\
2 \\
5 \\
1\end{array}$ & $\begin{array}{l}0 \\
0 \\
1 \\
0 \\
1 \\
1 \\
0 \\
0 \\
0 \\
1 \\
3 \\
0\end{array}$ & $\begin{array}{l}0 \\
0 \\
\text { I } \\
0 \\
0 \\
1 \\
0 \\
0 \\
0 \\
1 \\
0 \\
1\end{array}$ & $\begin{array}{l}0 \\
0 \\
2 \\
0 \\
1 \\
1 \\
2 \\
0 \\
0 \\
0 \\
2 \\
3 \\
\mathbf{1}\end{array}$ & $\begin{array}{r}- \\
12 \cdot 5 \\
16 \\
0 \\
13 \\
5 \\
7 \\
6 \\
16 \\
4 \\
7 \\
17\end{array}$ \\
\hline Total & 372 & 98 & 470 & 18 & 6 & 24 & 7 & 4 & II & $7 \cdot 45$ \\
\hline
\end{tabular}




\section{Discussion}

G6PD Deficiency. While the number of defificient individuals uncovered is extremely small, the results are of considerable interest. Thus while no G6PD deficient individuals were found among 72 non-gypsy Macedonian males (series A, B, D), 2 probably heterozygous individuals were found among 20 such females. By the method of maximum likelihood these results lead to an estimate of the gene determining G6PD deficiency in this group as the solution for $\mathrm{q}$ of the equation

$$
\frac{2}{\mathrm{q}}=\frac{2+36+72}{\mathrm{I}-\mathrm{q}} \text { or } \mathrm{q}=0.018,
$$

which is not dissimilar to the frequency found by Stamatoyannopoulos and Panayotopoulos (1965) among male Greek air force recruits from prefectures in the adjoining parts of Greek Macedonia. The apparent absence of G6PD deficiency among the 72 males is puzzling but may be due to chance variation though the possibility of strong selection against enzyme-deficient males, as, for example, through profound neonatal jaundice (Doxiadis, Fessas, and Valaes, 1961), or through favism cannot be excluded.

The high frequency of G6PD deficiency among the gypsies of Skopje (series C-2 of 34 males deficient and 2 of 8 females, one of whom could possibly be an abnormal homozygote) is worthy of note. In this instance, assuming that the female with a BCB decolorization time of more than 24 hours is a heterozygote rather than a homozygote for the gene causing G6PD deficiency, an estimate of the frequency of this gene is given as the solution for $\mathrm{q}$ of the equation:

$$
\frac{2+2}{q}=\frac{32+2+12}{1-q} \text { and } q=0.080 .
$$

If on the other hand this female is assumed to be a homozygote, then

$$
\frac{2+2+I}{q}=\frac{32+12+I}{I-q} \text { and } q=0.100 \text {. }
$$

G6PD deficiency with a frequency of 3-19\% has been described in samples of Indian males (Vella, 196I; Motulsky and Campbell-Kraut, 196r; Baxi, Balakrishnan, Undevia, and Sanghvi, I963; Meera Khan, 1964; M. Siniscalco, 1964, personal communication) and, though no comparable series of gypsies has been tested, those of the Balkans in particular are thought to be of relatively pure Indian origin (Schade and Pilarić, 196I). It is probable, moreover, that both the complete ('Caucasian' type with BCB decolorization times of 6 hours and more) and the partial ('Negro' type with BCB decolorization times of 2-4 hours) forms of G6P足 deficiency exist among Indians (Meera Kha 1964; M. Siniscalco, 1964, personal communication it is interesting, therefore, that the two deficiet males of series C seem to represent both the variants.

Of 387 males from the Dalmatian coast and i hinterland, 3 showed BCB decolorization times excess of 2 hours and must be regarded as deficiend. While this is a very low frequency $(0.8 \%)$, it is by no means negligible and it is of the utmost interest that, in contrast to most Caucasian enzyme-defici ent individuals, all these 3 Dalmatians show the partial variant of deficiency as defined above. Two of them, though unrelated, came from the same small fishing village of Hodilje to the north of Dubrovnik (series F) while the third (series $\frac{\mathrm{E}}{\mathrm{J}}$ was born in the small island of Lastovo, also neagr Dubrovnik.

G6PD deficiency does exist elsewhere on the Dalmatian coast and undoubted clinical histories of favism have been described in two sibships of $\frac{\widehat{3}}{3}$ and 3 brothers, respectively, originating in Zadar (series I) by Vince-Ribarić (1962).

It is interesting to speculate on the origin of the variant gene causing partial G6PD deficiency in this population. Negroes were introduced in various capae ties but usually as slaves into the Balkan peninsula duriog the Turkish conquest and are still found in Yugoslarga (Dordević, 1933). Even though, through the exercige of skilful diplomacy, the mercantile republic of Dubro nik or Ragusa was never subject to the Turks, it is least possible theoretically that a negro gene is involvec. Some negro slaves were in fact introduced not by Tud but by Montenegrin pirates (Lopashich, 1958). Support for the presence of negro admixture in the Balkans afforded by the finding of the serum group Gm (e) segregating in several families of two villages of the A region of Greece (A. G. Steinberg, I964, persomal communication). The gene determining the $\mathrm{Gm}$ (8) group had previously been found only in negroes.

Stamatoyannopoulos, Panayotopoulos, and Papayanopoulou (1964) have, however, raised another possiglity by their finding that the enzyme from partialy deficient Greek individuals does not migrate electiophoretically like the negro variety. It may be, therefofe, that partial G6PD deficiency in the Balkans is a relic of a very old polymorphism which was already presit among the peoples that inhabited the peninsula befofte the coming of the Greeks and Slavs. The spread of the complete variety of G6PD deficiency on the other hand, found mainly in Greek, Sardinian, Balearic, and Sephardic Jewish populations in the Mediterranean arg, could conceivably be attributed to the Phoenicians (Sheba, I963) who traded and settled extensively in the Mediterranean in the pre-Christian era but who pro $\$$ ably did not penetrate the Dalmatian littoral. It is $\mathbb{Q}_{\mathrm{f}}$ interest that the extensive Greek colonization of DA- 
matia about 700 B.C. does not seem to have introduced the complete variety of G6PD deficiency to any great extent, though possibly the cases of favism described by Vince-Ribarić (1962), referred to above, may reflect such an origin.

Abnormal Haemoglobins. The finding of a haemoglobin apparently identical with that characterized as Pylos in several Greek families (Fessas et al., 1962) in one male of series $L$ is of some interest. It is thought that this haemoglobin, like haemoglobin Lepore found in an Italian family (Gerald and Diamond, 1958), is a hybrid product of $\beta$ and $\delta$ chains and arises by a process of unequal crossing-over and subsequent deletion of part of the chromosome segment responsible for the synthesis of $\beta$ and $\delta$ polypeptide chains (Baglioni, 1962). Morphological abnormalities of the erythrocytes similar to those found in $\beta$-thalassaemia are normally associated with heterozygosis for $\mathrm{Hb}$ Pylos, but unfortunately no slide was available in the individual from series $L$ of the present survey, who was born in the Croatian town of Cakovec near the Hungarian border. Furthermore no studies of the family of this person have been possible.

A male, originating from Rijeka, also sampled in series $L$, had a raised level of foetal haemoglobin (I0\% of the total). The blood film was normal, and this finding may represent heterozygosis for a gene causing hereditary persistence of foetal haemoglobin such as has been found in Greek (Fessas and Stamatoyannopoulos, 1964) and Italian (Manganelli, Dalfino, and Tannoia, 1962) families. The quantity of foetal haemoglobin detected in this isolated Yugoslav case corresponds well with the findings in Greece rather than with the higher percentage in negro (Conley, Weatherall, Richardson, Shepard, and Charache, 1963) and Indian (Barkhan and Adinolfi, 1962) persons heterozygous for a gene causing hereditary persistence of foetal haemoglobin. A family study of the Yugoslav individual of the present series with a high $F$ gene unfortunately could not be undertaken.

Thalassaemia. The high frequency of $\beta$ thalassaemia trait, as shown in this survey and by numerous case reports by investigators from all parts of Yugoslavia (Kostić-Joksić and Stefanović, 1952; Kocijančič, I956; Škrabalo, 1956; Kotevska, 1959; Matajc and Savnik, 1960; Sadikario, Grozdanov, and Levi, 1960; Matajc, 196I ; Premužić, 1962; Ruvidić, Rolović, Pendić, and Kostić, I962; Milić, Sekso, and Dević-Mikac, 1964), is of great interest. The prevalence of thalassaemia, as uncovered in this survey, does not appear to be strikingly different between the regions sampled $\left(\chi_{10}^{2}\right.$ for heterogeneity between the II series is 9.10; $p>0 \cdot 10$ ), neither does the study of birthplaces of affected individuals reveal any aggregation in the geographical origin of cases.

While the findings in Macedonians, both Slav and Gypsy, could have been forecast from the presence of thalassaemic conditions in Greek Macedonians (Malamos et al., 1962), Indians (Chatterjea, Swarup, Ghosh, and Ray, 1957), and gypsies (Zilliacus and Ottelin, I963), the high frequency along the entire Dalmatian coast is surprising even though some of the case reports in the Yugoslav literature concern patients from this area. These data show that the distribution of thalassaemia is continuous from Greece to the Adriatic Italian littoral and the Po delta (Silvestroni and Bianco, 1963) and possibly northward to Hungary (Kahán, Kahán and Benkö, 1963), and these facts may have some bearing on theories of the origin and spread of the thalassaemia gene in the Mediterranean. Zaino (1964a) has postulated that thalassaemia originated in a Mediterranean valley connecting Europe and Africa, and including Sicily, which existed 50,000 years ago. It is clear, however, that one of his central arguments in support of this hypothesis, that thalassaemia is uncommon in Yugoslavia (Zaino, 1964b), is no longer tenable.

Blood films were available from 7 of the 9 persons who gave indication of abnormal G6PD activity ( 4 males and 3 females). In no case did the film show any erythrocyte abnormality indicative of $\beta$-thalassaemia, suggesting that no undue concentration of carriers of both genes occurs in the Yugoslav population.

G6PD Deficiency and Colour Blindness. Siniscalco, Bernini, and Latte (1963) suggested that, in the Sardinian population, the prevalence of red-green colour blindness was positively correlated with that of G6PD deficiency and that an excess association of the two abnormal genes in the coupling phase occurred. This phenomenon was attributed to positive selection for the gene for colour blindness because of its adjacent position to that for G6PD deficiency when in coupling, strong selection taking place in favour of this latter gene on account of the advantage of heterozygotes and/or hemizygotes with regard to malaria. This hypothesis has not been confirmed in negro (Porter, Schulze, and McKusick, 1962), Kurdish and Iraqi Jewish (Adam, 1963), or Greek (Fraser, Defaranas, Kattamis, Race, Sanger, and Stamatoyannopoulos, 1964) populations, though from these studies close linkage between the two genes is not in doubt.

In the present survey very sparse data bearing on these points are available, since in only two fully tested groups (series $\mathrm{C}$ and $\mathrm{F}$ ) were both abnormal genes 
detected. In series $\mathbf{F}$ two males were partially G6PD deficient, two were colour blind, and no case of double abnormality occurred. In series $\mathbf{C}$ the male with partial G6PD deficiency was also colour blind, but the male with complete enzyme deficiency had normal colour vision and one further colour blind G6PD normal male was detected in the same series. Clearly these findings are numerically inadequate and no conclusions regarding the possible relationship of G6PD deficiency and colour blindness in the Yugoslav population can be drawn from them. The one gypsy male with both abnormal genes could well have owed his double deficiency to chance.

\section{Summary}

Five examples of G6PD deficiency (4 partial, I complete) were found in blood samples from 493 male Yugoslavs, and 4 of the 28 females tested were heterozygous for this gene. Abnormal haemoglobins seem to be rare in the Yugoslav population and only one example of haemoglobin Pylos and one of hereditary persistence of foetal haemoglobin were found among 560 samples studied. Suggestive evidence is presented, on the other hand, that a moderately high incidence of $\beta$-thalassaemia trait exists in Yugoslav Macedonia and on the Dalmatian coast, areas where malaria was previously hyperendemic.

We are grateful to numerous colleagues in Yugoslavia who helped us in the collection of the blood samples. Mrs. J. Keil, Mrs. A. Morrow, and Mrs. L. Steinmann of Seattle provided valuable technical assistance. We would like to thank Professor A. G. Motulsky for his advice and guidance and Dr. Ph. Fessas for providing laboratory facilities.

\section{REFBRENCES}

Adam, A. (1963). Linkage between G-6-PD deficiency and colour blindness. In Proc. 2nd Int. Congr. Hum. Genet., p. 565. Istituto G. Mendel, Rome.

Baglioni, C. (1962). The fusion of two peptide chains in hemoglobin Lepore and its interpretation as a genetic deletion. Proc. nat. Acad. Sci. (Wash.), 48, 1880.

Barkhan, P., and Adinolf, M. (1962). Observations on the high foetal haemoglobin gene and its interaction with the thalassaemia gene. F. clin. Path., 15, 350.

Baxi, A. J., Balakrishnan, V., Undevia, J. V., and Sanghvi, L. D. (r963). Glucose-6-phosphate dehydrogenase deficiency in the Parsee community, Bombay. Indian f. med. Sci., 17, 493.

Brewer, G. J., Tarlov, A. R., and Alving, A. S. (1960). Methamoglobin reduction test: a new simple, in vitro test for identifying primaquine-sensitivity. Bull Wld Hlth Org., 22, 633.

Chatterjea, J. B., Swarup, S., Ghosh, S. K., and Ray, R. N. (1957). Incidence of haemoglobin $\mathrm{E}$ and 'thalassaemia trait' in Bengalees. Bull. Calcutta Sch. trop. Med., 5, 159.

Conley, C. L., Weatherall, D. J., Richardson, S. N., Shepard, M.K., and Charache, S. (1963). Hereditary persistence of fetal hemoglobin: a study of 79 affected persons in 15 Negro families in Baltimore. Blood, 21, 26r.

Dordević, T. R. (1933). Negri u našoj zemlji. In Naక Narodni Život, p. 58. Kona, Belgrade.
Doxiadis, S. A., Fessas, Ph., and Valaes, T. (I96I). Glucosephosphate dehydrogenase deficiency. A new aetiological factor $\overline{d f}$ severe neonatal jaundice. Lancet, I, 297.

Fessas, P., and Stamatoyannopoulos, G. (1964). Hereditary persis: tence of fetal hemoglobin in Greece. A study and a comparison. Blood, 24, 223.

- - $\longrightarrow$, and Karaklis, A. (I962). Hemoglobin "Pylos": stu円y of a hemoglobinopathy resembling thalassemia in the heterow" gous, homozygous and double heterozygous state. ibid., I9, I. $\overline{\bar{A}}$

Fraser, G. R., Defaranas, B., Kattamis, C. A., Race, R. R., Sange R., and Stamatoyannopoulos, G. (I964). Glucose-6-phosphse dehydrogenase, colour vision and $X_{g}$ blood groups in Greeç: linkage and population data. Ann. hum. Genet., 27, 395.

Gerald, P. S., and Diamond, L. K. (1958). A new hereditary hemoglobinopathy (the Lepore trait) and its interaction wth thalassemia trait. Blood, r3, 835.

Kahán, A., Kahán, I. L., and Benkö, A. (1963). Erythrocytic anomalies in hereditary vitreo-retinal degeneration (degenerato hyaloideoretinalis). Brit. F. Ophthal., 47, 620.

Kocijančic, K. (1956). Primer mediteranske anemije pri nå. Zdrav. Vestn., 25, 463.

Kostić-Joksić, S. A., and Stefanović, S. (I952). Slučaj eritroblastine hemolitične anemije Cooley-evog tipa. Srpski Arkh. tseleb. Lek., 80, I 178.

c

Kotevska, R. (1959). Po povod 12 slučai na Cooley-evata anemira. Makedon. med. Pregl., I4, 60.

Lopashich, A. (1958). A Negro community in Yugoslavia. Man, 58, 169.

Malamos, B., Fessas, P., and Stamatoyannopoulos, G. (1968). Types of thalassaemia-trait carriers as revealed by a study $\widehat{\rho}$ their incidence in Greece. Brit. F. Haemat., 8, 5.

Manganelli, G., Dalfino, G., and Tannoia, N. (1962). Su di $\vec{u}$ caso di associazone tra talassemia e "persistenza ereditaria gi
emoglobine fetale". Haematologica, 47, 353 .

Matajc, L. (I96I). Sodobne metode ugotavljanja lažjih obuik mediteranskih anemij. Zdrav. Vestn., 30, 29.

-, and Savnik, B. (1960). Hemoglobinopatije. ibid., 29, 53.

Meera Khan, P. (1964). Glucose-6-phosphate dehydrogenge deficiency in an Indian rural area. F. Genet., 59, 14.

Milić, N., Sekso, M., and Devic-Mikac, D. (1964). Prilog pozt vanju talasemije. Anali Bolnice 'Dr. M. Stojanovic'. Zagr., 3, 48.

Motulsky, A. G. (I964). Hereditary red cell traits and malariat. Amer. F. trop. Med., 13, 147.

$\longrightarrow$, and Campbell-Kraut, J. M. (196r). Population genetics $\widehat{\gamma}_{f}$ glucose-6-phosphate dehydrogenase deficiency of the red cen In Proc. Conf. on Genetic Polymorphisms and Geographic Varitions in Disease, ed. B. S. Blumberg. p. 159. Grune and Strattón, New York.

Porter, I. H., Schulze, J., and McKusick, V. A. (1962). Genetical linkage between the loci for glucose-6-phosphate dehydrogendige deficiency and colour-blindness in American Negroes. Ann. hut Genet., 26, 107.

Premužić, M. (1962). Thalassaemia minima. Liječn. Vjesn., : 1135.

Ruvidić, R., Rolović, Z., Pendić, S., and Kostić, K. (1962). Sluçă talasemije minor. ibid., 84,673 .

Sadikario, A., Grozdanov, G., and Levi, S. (1960). Talasemije kao klinicki i socijalnomedicinski problem. God. Sborn. mats. Fak. Skopye, 7, 137.

Schade, H., and Pilarić, G. (I96r). Anthropologischer Bericbt über Zigeuner in Jugoslawien; zugleich ein Beitrag zur Frage $10 \mathrm{r}$ Brachycephalisation. Homo., I2, 185.

Sheba, C. (1963). Environmental vs. ethnic factors determining the frequency of G6PD deficiency. In The Genetics of Migrant difte Isolate Populations, ed. E. Godschmidt, p. roo. Williams agd
Wilkins, New York.

Silvestroni, E., and Bianco, I. (1963). Le Emoglobine Umane. Biochimica, Genetica, Popolazionistica, Patologia e Clinica. Instit年o G. Mendel, Rome.

Simić, C. (1956). Le paludisme en Yougoslovie. Bull. Wld Hith Org., I5, 753.

Siniscalco, M., Bernini, B., and Latte, B. (1963). Linkage data involving G-6-PD deficiency, colour blindness and haemophit In Proc. 2nd Int. Cong. Hum. Genet., p. 564. Istituto G. Mendẹ, Rome. 
Škrabalo, Z. (1956). Slučaj thalassemiae minor. Liječn. Vjesn., 78, 364.

Stamatoyannopoulos, G., and Fessas, Ph. (1964). Thalassaemia, glucose-6-phosphate dehydrogenase deficiency, sickling, and malarial endemicity in Greece: A study of five areas. Brit. med. F., r, 875 .

, and Panayotopoulos, A. (1965). Geographical distribution of glucose-6-phosphate dehydrogenase deficiency in Greece. In preparation.

$\longrightarrow$, - and Papayannopoulou, T. (1964). Mild glucose-6phosphate dehydrogenase deficiency in Greek males. Lancet, 2, 932.
Vella, F. (196I). The incidence of erythrocyte glucose-6-phosphate dehydrogenase deficiency in Singapore. Experientia (Basal)), 17, I8r.

Vince-Ribarić, V. (1962). Klinićki prilog upoznavanju favizma. Liječn. Vjesn., 84, $15 \mathrm{r}$.

Zaino, E. C. (1964a). Paleontologic thalassemia. Ann. N.Y. Acad. Sci., 119, 402.

- (1964b). Panel discussion on problems of Cooley's anemia. ibid., 119, 798.

Zilliacus, H., and Ottelin, A. M. (1963). A thalassaemic trait in gypsies? Acta med. scand., 174, $26 \mathrm{r}$. 